DOI: $10.1515 /$ pts-2014-0035

PHYSICS IN ENGINEERING

\title{
DEVELOPED DESIGN FOR HUMERAL HEAD REPLACEMENT USING 3D SURFACE MAPPING
}

\author{
Salah H. R. Ali \\ National Institute for Standards, \\ Eng. and Surface Metrology, Precision Engineering Division, \\ Giza 12211-136, EGYPT \\ SalahAli20@yahoo.com
}

\begin{abstract}
Assessment of dimensional and geometrical data on the humeral head replacement (HHR) objects is essential for solving the relevant designing problems in the physics of reverse engineering (RE). In this work, 2D-assessment for human humerus was performed using the computed tomography (CT) technique within the RE plan, after which the 2D images of humeral objects were converted into 3D images. The conversion was successful and indicated a clear difference in the 2D and 3D estimates of sizes and geometry of the humerus. The authors have analyzed and confirmed experimentally the statistical information on the relevant anatomical objects. The results of finite-element simulation of the compressive stresses affecting the geometry of 3D surface mapping were analyzed using SolidWorks software. For developing the biomechanical design of an HHR object suitable biomaterials were selected, and different metal-based biomaterials are discussed as applied at various loads. New methodology is presented for the size estimation of humeral head - both anatomical and artificial - in 3D-shape. A detailed interpretation is given for the results of CT D-measurements.
\end{abstract}

Keywords: humeral head, dimensional assessment, image metrology, HHR design, 3D surface mapping.

\section{INTRODUCTION}

Dimensional metrology plays a highly important role in the plastic surgery, especially concerning the human joint replacement. This metrology, with inclusion of the X-ray computed tomography (CT) technique and image processing, is a significant tool of designing the engineering objects [1-3].

The anatomical human joint is the location of two or more connected elements or objects. From the viewpoint of engineering the human shoulder joint is a natural wonder. The shoulder joint is constructed to allow its movement and provide mechanical support; it consists of four main parts, numerous ligaments and muscles working synergistically [4]. The humeral head $(\mathrm{HH})$ - a ball (half-sphere) located at the upper end of humerus - is an important object in the replacement of a human shoulder joint [5]. Patients treated for glenoid problems may require revision to the total shoulder arthroplasty due to the $\mathrm{HH}$ arthrosis. Therefore, the 3D surface map- 
ping for developed design of an HHR object deserves a wide analysis.

In this paper, the CT technique is used to obtain precise dimensions and geometric shape of humeral head, with validation and simulation of the design proposed for the metrology of HHR objects as a reverse engineering (RE) tool. The finite-element (FE) analysis for 3D surface mapping is used to study the mechanical behavior of a humeral head in real-life situations.

For visualization of humeral head - both anatomical and made of artificial materials - a method is proposed which has been confirmed by FE analysis of both compression stresses and surface deformations for developed HHR object in 3D mapping. We also describe a biomechanical design proposed for the humeral head. The results of our studies would make it possible to better optimize this design so that it is suitable for the total shoulder joint replacement.

\section{MATERIALS AND METHODS}

The artificial materials for human joints in most joint implants are combined from two components, one of them from metal and the other from polymer [6]. The two implanted components can rub together smoothly, while minimizing debris based on the frictional wear mechanism. The most common metal bases for biomaterials used in orthopaedic implants are aluminum foam as well as cobalt-chromium and nickel-titanium alloys. In this work, of importance are the dimensions and geometrical shape of the anatomical shoulder humerus as a target object. Physical and mechanical properties of the selected biomaterials are presented in Table 1.

Table 1

Physical and mechanical specifications of biomaterials for HHR design

\begin{tabular}{ccccc}
\hline Biomaterial & $\begin{array}{c}\text { Density } \\
\left(\mathrm{Kg} / \mathrm{m}^{3}\right)\end{array}$ & $\begin{array}{c}\text { Elasticity } \\
\text { modulus (MPa) }\end{array}$ & Poisson's ratio & $\begin{array}{c}\text { Comp. strength } \\
(\mathrm{MPa})\end{array}$ \\
\hline Co-Cr [7] & 8300 & 210000 & 0.30 & 1150 \\
Ni-Ti [8] & 6450 & 79000 & 0.33 & 895 \\
Al-foam [9] & 900 & 6000 & 0.32 & 30 \\
Bone [10] & 1900 & 17200 & 0.32 & 135 \\
\hline
\end{tabular}

For the computed tomography a HiSpeed-dual machine was used. Under investigation were four cases corresponding to the number of healthy young volunteers. The CT measurement procedures were controlled by the experts in anatomy and radiology using the $\mathrm{CT}$ method for displaying the 2D transverse section images. The digital conversion of $2 \mathrm{D}$ standard images in the $\mathrm{DICOM}^{*}$ format into $3 \mathrm{D}$ images with precise dimensions required the use of special computer programs such as Vesalius, MeshLab and 3-matic packages. The InVesalius version was used to read the standard 2D DICOM data generated from CT, and to construct the 3D standard triangle language (STL) model. The 3D visualization by images is of significant interest for understanding the properties of $\mathrm{HH}$ surface structure. The processing of 3D STL data was performed by the 3D editing MeshLab software. Conversion of the 3D model required the use of special 3-matic software - the unique software 
which is able to endow the AutoCAD tool with pre-processing (meshing) capabilities [11]. The standard deviation (SD) in the measurements was calculated using the n-1 method:

$$
S D=\sqrt{\frac{\sum\left(x-x^{\prime}\right)^{2}}{(n-1)}}
$$

where $n$ is the number of measurement runs.

The SolidWorks software is a $3 \mathrm{D}$ computer-aided design (CAD) running under MS Windows package. The software uses the FE method to compute the results of stresses and displacements relative to the geometry of the parts under internal and external applied loads, thus making it possible to optimize and validate each design in order to ensure its quality, performance and safety [12]. In this work, SolidWorks-2013 software was applied for analyzing the stress distribution and displacement of surface deformations. This was done in 3D for different suitable biomaterials at various loads applied to a HHR object.

\section{SETTING UP AND PROCESSING}

The work was set up in three main phases or processes. The first was measuring of the right shoulder humerus for four volunteers using CT technique in 2D images at the same conditions. The second one deals with using the software packages for conversion of the anatomical humerus 2D-CT images to 2D-DICOM, 3D STL and then to $3 \mathrm{D}$ images. The third phase is the complete conversion procedures from 2D image into 3D solid body, which are done as follows.

- Measuring the dimensions of the object using the HiSpeed CT scan technique.

- Converting the CT scan 2D-image into 2D data using DICOM reader software.

- Converting the DICOM data into a 3D STL model by InVesalius software.

- Editing the 3D-model and smoothing by means of MeshLab.

- Editing the 3D solid-body using 3-matic software.

The conversion aims at obtaining a clear field of details in the assessment of dimensions and geometry of the proposed HHR design. The third stage of the process is based on the use of SolidWorks software package in order to build the 3D maps of the proposed humeral head and clarify the extent of changes in the geometric mapping at different designing conditions.

\subsection{CT measurement and 2D-3D image conversion}

The CT scan images have been done and stored in the DICOM form, which cannot be easily decoded to visualize the actual image without proper hardware that is normally associated with the scanner. The cost of such a system is very high; therefore, it was necessary to visualize these images in the proper form to make them helpful for medical practitioners as well as for engineers so that they could better understand the anatomical structure or the abnormalities associated with the patient [13]. Special InVesalius software was used to read the 2D DICOM data generated 
by CT method and then to construct a 3D STL model of the humerus bone that was exposed to radiation (Fig.1). The data processing and editing 3D STL was performed using 3D MeshLab software (an open source program - a portable and extensible system for processing and editing the unstructured 3D triangular meshes). Figure 2 shows the results of editing process. The visualization capability for conversion into $3 \mathrm{D}$ image of the humerus is presented in Fig. $2 b$. Now, it becomes possible to have a 3D solid body image from the 2D DICOM data generated by CT method.
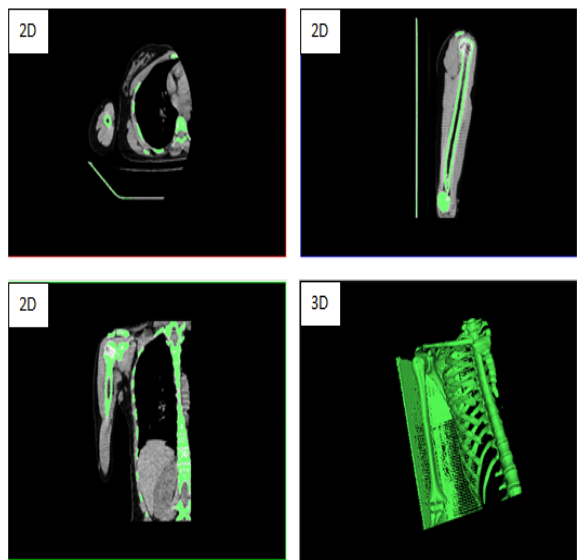

Fig.1. The 3D model generated from 2D-CT image using InVesalius software
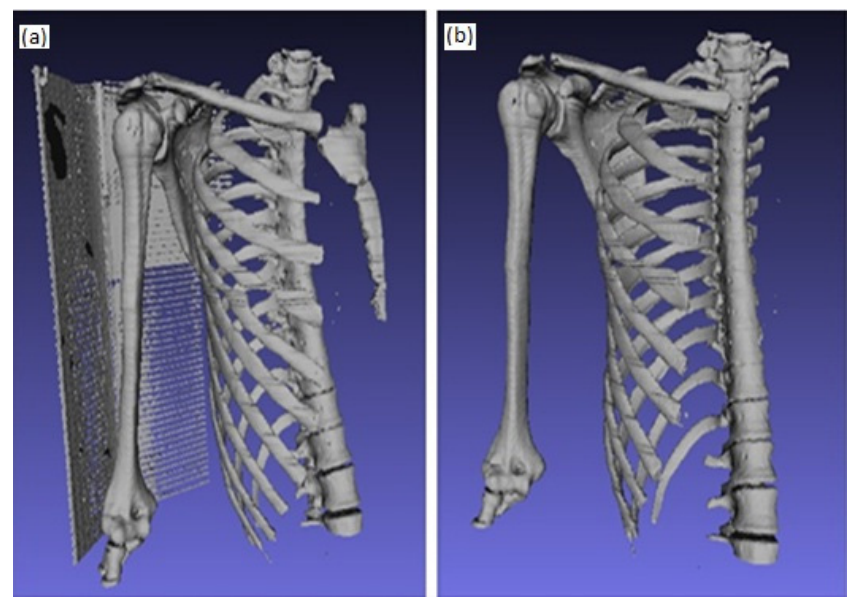

Fig.2. A 3D solid body for the right chest and shoulder joint: (a) before editing (b) after editing

\subsection{Dimensional Measurement of Anatomical Humerus}

To provide a better way for designing artificial humerus for replacement, it is important to know precisely the anatomical dimensions; besides, it is necessary to select the most efficient biomaterials that are suitable for the HHR and, therefore, to measure and analyze the anatomical dimensions. The 3D images generated from 2D-CT ones for four right-shoulder humeri of the volunteers (two males and two females) were measured using MeshLab software. Table 2 gives the comparative results obtained at room temperature. 
Comparative data for four volunteers

\begin{tabular}{|l|c|c|c|c|}
\hline \multirow{2}{*}{ Parameters of volunteer } & \multicolumn{2}{|c|}{ Females } & \multicolumn{2}{c|}{ Males } \\
\cline { 2 - 5 } & $\mathrm{F} \# 1$ & $\mathrm{~F} \# 2$ & $\mathrm{M} \# 1$ & $\mathrm{M} \# 2$ \\
\hline Age, years & 21 & 21 & 24 & 21 \\
\hline Weight, $\mathrm{kg}$ & 60 & 56 & 73 & 76 \\
\hline Height, cm & 163 & 157 & 180 & 183 \\
\hline $\begin{array}{l}\text { Bone density, } \\
\mathrm{kg} / \mathrm{m}^{3} \text { (Hounsfield) }\end{array}$ & 1561.50 & 1286.67 & 2042.67 & 1522.33 \\
\hline
\end{tabular}

Figure 3 shows four commonly measured dimensions of humerus bone:

- $\quad$ Part I, Length A-B: the maximum height of the humerus.

- Part II, Section C-D: the humeral head diameter.

- Part III, Section E-F: the bone width at the median.

- $\quad$ Part IV, Section G-H: the trochlea humerus.

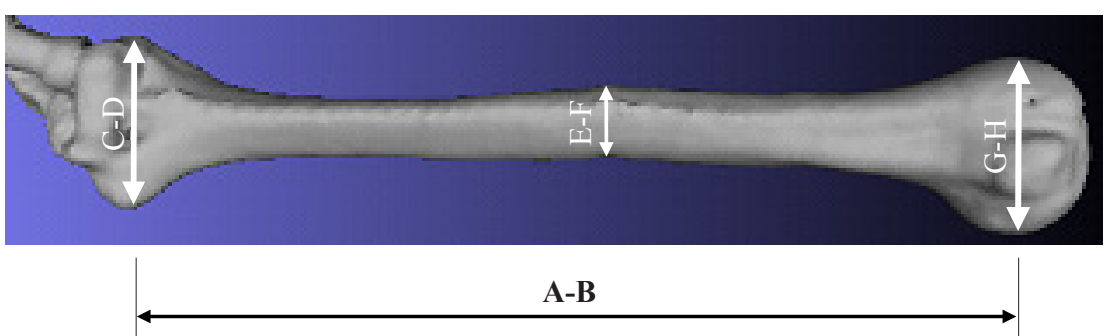

Fig.3. Dimensions of human humerus bone

\subsection{Dimensional Analysis of Anatomical Humerus}

Measurement results must have a degree of doubt, regardless of precision and accuracy. This is caused by two factors: the limitation of the measuring instrument and the skill of the person making the measurements [14]. Therefore, we have calculated the average measured values and the standard measurement deviations. The results for different positions of humerus are presented in Fig.4, where difference between these values for females and males is clearly seen.

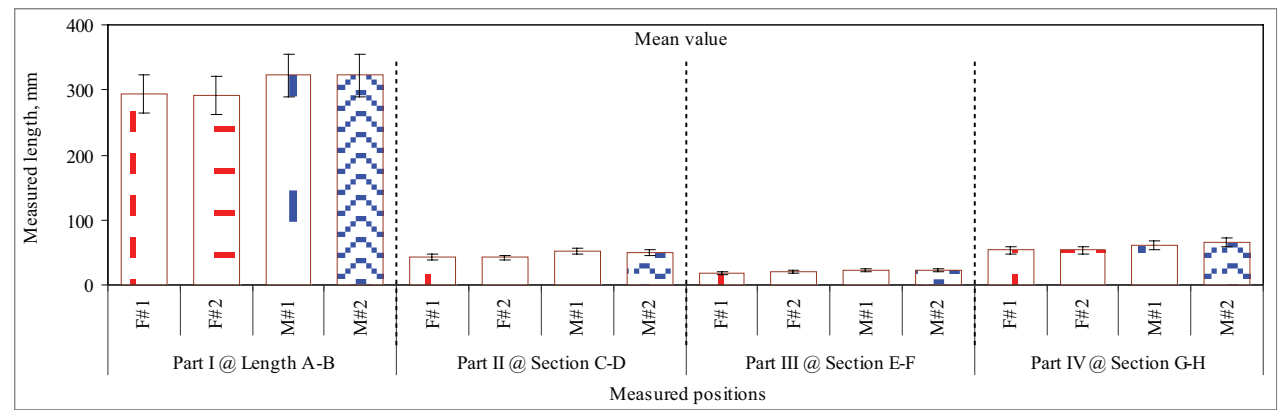

Fig.4. The mean of dimensional measurement results for anatomical humerus bone 
The anatomical humerus length (A-B) varied from $291.97 \mathrm{~mm}$ to $294.77 \mathrm{~mm}$ (standard deviation $\pm 1.39 \mathrm{~mm}$ ) in females and from $322.12 \mathrm{~mm}$ to $322.36 \mathrm{~mm}$ (standard deviation $\pm 0.12 \mathrm{~mm}$ ) in males. The average in all measurements is $293.36 \mathrm{~mm}$ and $322.24 \mathrm{~mm}$ for females and males, (standard deviation $\pm 14.44 \mathrm{~mm}$ ). Thus, it can be inferred that the observed difference in dimensions of anatomical humerus is probably due to genetics and environmental conditions of human life.

\subsection{Confirmation of the Measurement Accuracy}

Previous researchers tried to compare and explain the phenomenon of difference in length between the right and left humeri of humans $[15,16]$. The average length of the humerus was found to be $344.8 \mathrm{~mm} \pm 0.63 \mathrm{~mm}$ for the males and 316.6 $\mathrm{mm} \pm 0.36 \mathrm{~mm}$ for the females [15]. In [16], the maximum length of the dry humeri for adults from sex-aggregated Indian population are reported to be $299.6 \mathrm{~mm} \pm 22.5$ $\mathrm{mm}$ and $309.6 \mathrm{~mm} \pm 20.6 \mathrm{~mm}$ for the left and the right hand, respectively. Thus, the average length of the left-hand humerus is here $304.6 \mathrm{~mm} \pm 7.1 \mathrm{~mm}$. One possible explanation for the humerus asymmetry is the handedness* [15]. In the present work, mean lengths were compared with the values recorded in other studies $[15,16]$.

The reported results on the humeral head length were $330.70 \mathrm{~mm} \pm 19.9 \mathrm{~mm}$ [15] and $304.6 \mathrm{~mm} \pm 7.1 \mathrm{~mm}$ [16], which is within the limits obtained in the present study (see Fig.5). Analysis of this comparison has confirmed that the measurement results of the present work are located within the upper limit (UL) and lower limit (LL) of the worldwide published international results. Therefore, it could be said that the presented results of D-measuring the human humerus bone are confirmed.

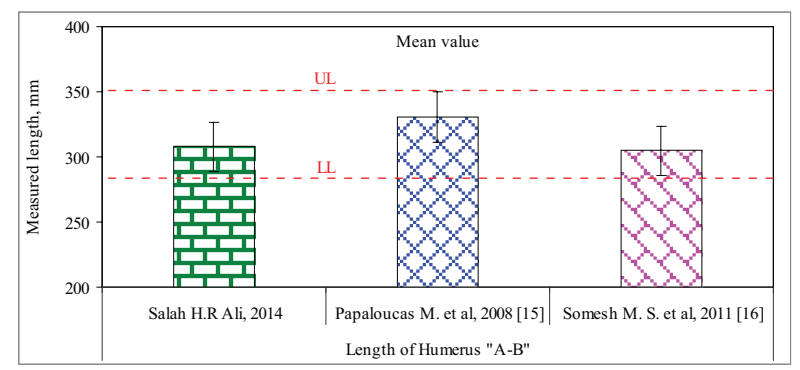

Fig.5. Comparison of the mean humerus sizes measured by different authors

\section{ANALYSIS OF 3D SURFACE MAPPING FOR ANATOMICAL HUMERAL HEAD}

The stress analysis and the surface deformation of anatomical humeral head are presented using the maximum von Mises stress criterion. Reconstruction of the bone geometry and artificial structures of the anatomical humeral head are illustrated in Fig.6, with more than 8058 and 5838 elements, respectively, meshed via SolidWorks software. In this figure, the details of boundary conditions obtained by the FE method are given for the anatomical and artificial HH shapes. The FE solid mesh analysis is optimal for understanding the behavior of each biomaterial under different compressive loads, thus helping to develop the biomechanical design of artificial $\mathrm{HH}$ shape that replicates the anatomical one.

*Handedness is the unequal distribution of kinetic skills between the left and right hands. 
(a)

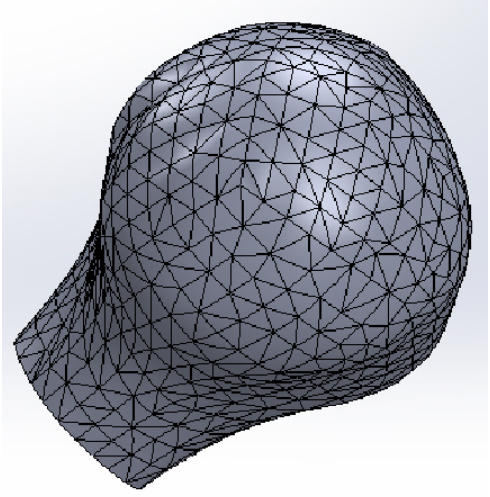

(b)

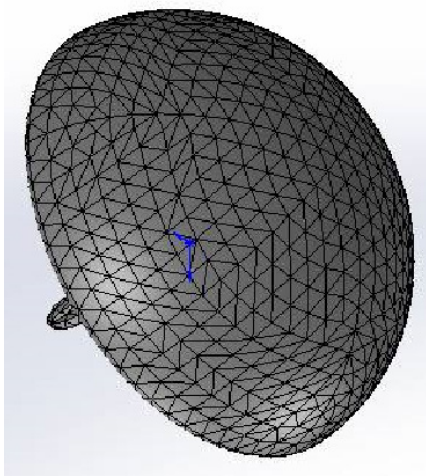

Fig. 6. Solid mesh of humeral head created in SolidWorks: (a) anatomical shape (number of nodes 12134; number of elements 8058); (b) artificial shape (number of nodes 10423; number of elements 5838)

\subsection{D Stress Analysis of the Proposed Design for Anatomical HH}

The simulation details of FE method are shown in Fig.7, where the data are acquired from the stress analysis of bone $\mathrm{HH}$ at the minimum and the maximum compression loads for Co-Cr alloy. In this figure it is seen that using the $50 \mathrm{~N}$ compression load gives the minimum stress point value of $26,404.4 \mathrm{~N} / \mathrm{m}^{2}$ and a maximum of $2,591,936.0 \mathrm{~N} / \mathrm{m}^{2}$. The use of $3000 \mathrm{~N}$ compression load leads to the minimum stress point value of $1,584,263.8 \mathrm{~N} / \mathrm{m}^{2}$ and the maximum of $755,516,160.0 \mathrm{~N} / \mathrm{m}^{2}$.

The compression stress analysis of Al-foam humeral head under $50 \mathrm{~N}$ and 3000 $\mathrm{N}$ loads gives the following stress point values: the minimum/maximum of 26624.8 $\mathrm{N} / \mathrm{m}^{2} / 12697708.1 \mathrm{~N} / \mathrm{m}^{2}$ and $1597571.2 \mathrm{~N} / \mathrm{m}^{2} / 761862496.0 \mathrm{~N} / \mathrm{m}^{2}$, respectively. Such analysis for $\mathrm{HH}$ from Ni-Ti alloy at $50 \mathrm{~N}$ and $3000 \mathrm{~N}$ compression load gives respectively: $26,035.3 \mathrm{~N} / \mathrm{m}^{2} / 12,297,728.0 \mathrm{~N} / \mathrm{m}^{2}$ and 1,562,117.8 N/m²/737,863,616.0 $\mathrm{N} / \mathrm{m}^{2}$. The same analysis for bone humeral head at $50 \mathrm{~N}$ and $3000 \mathrm{~N}$ compression load gives respectively: $26,100.5 \mathrm{~N} / \mathrm{m}^{2} / 12,399,809.0 \mathrm{~N} / \mathrm{m}^{2}$ and 1,566,032.5 N/ $\mathrm{m}^{2} / 743,988,544.0 \mathrm{~N} / \mathrm{m}^{2}$.

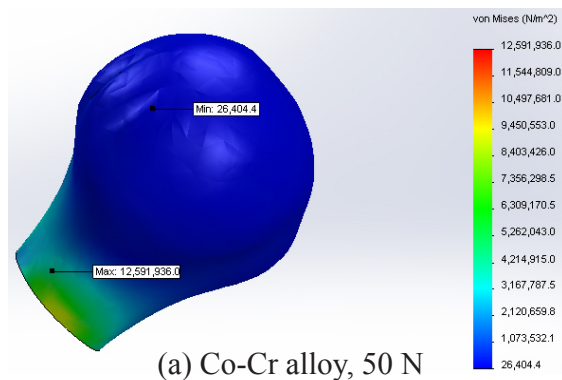

(a) Co-Cr alloy, $50 \mathrm{~N}$

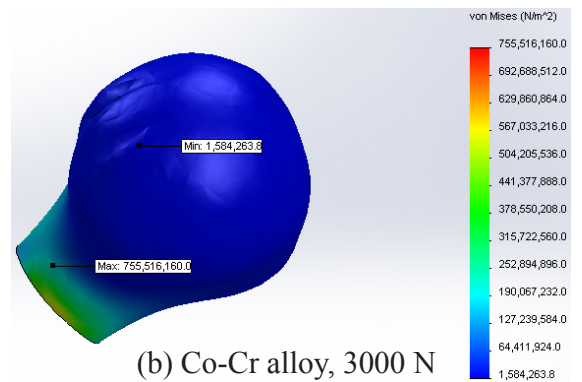

(b) Co-Cr alloy, $3000 \mathrm{~N}$

Fig.7. 3D stress distribution over humeral head

Comparative results of stress analysis for anatomical humeral head - both natural bone and the replications from Al-foam, $\mathrm{Co}-\mathrm{Cr}$ and $\mathrm{Ni}-\mathrm{Ti}$ alloys - at the minimum and the maximum compression loads are presented in Table 3. 
The maximum/minimum compression stress points $\left(\mathrm{N} / \mathrm{m}^{2}\right)$ for humeral head

\begin{tabular}{|c|c|c|c|c|}
\hline Load, N & Bone & Al-foam & Co-Cr & Ni-Ti \\
\hline 50 & $26101 / 12399809$ & $26625 / 12697708$ & $26404 / 12591936$ & $26035 / 12297728$ \\
\hline 3000 & $1566032 / 743988544$ & $1597571 / 761862496$ & $1584263 / 755516160$ & $1562118 / 737863616$ \\
\hline
\end{tabular}

\subsection{D Surface Deformation Analysis of the Proposed Design for Ana- tomical HH}

The details of simulated behavior of HH surface deformation obtained by the relevant analysis using SolidWorks are shown in Fig. 8 for $\mathrm{Co}-\mathrm{Cr}$ at the minimum $(50 \mathrm{~N})$ and the maximum $(3000 \mathrm{~N})$ compressive loads. In the former case the minimum displacement was $1.000 \mathrm{E}-030 \mathrm{~mm}$ and the maximum $-1.676 \mathrm{E}-003 \mathrm{~mm}$. In the latter case (using $3000 \mathrm{~N}$ compressive load) the minimum displacement was also $1.000 \mathrm{E}-030 \mathrm{~mm}$ and the maximum $-1.006 \mathrm{E}-001 \mathrm{~mm}$. The results of deformation analysis for the Ni-Ti humeral head at different compression loads (not illustrated by a figure) are as follows. In the case of $50 \mathrm{~N}$ compression load the minimum displacement was $1.000 \mathrm{E}-030 \mathrm{~mm}$ and the maximum $-4.430 \mathrm{E}-003 \mathrm{~mm}$. Using 3000 $\mathrm{N}$ compression load leads to the minimum displacement of $1.000 \mathrm{E}-030 \mathrm{~mm}$ and the maximum of $2.658 \mathrm{E}-001 \mathrm{~mm}$.
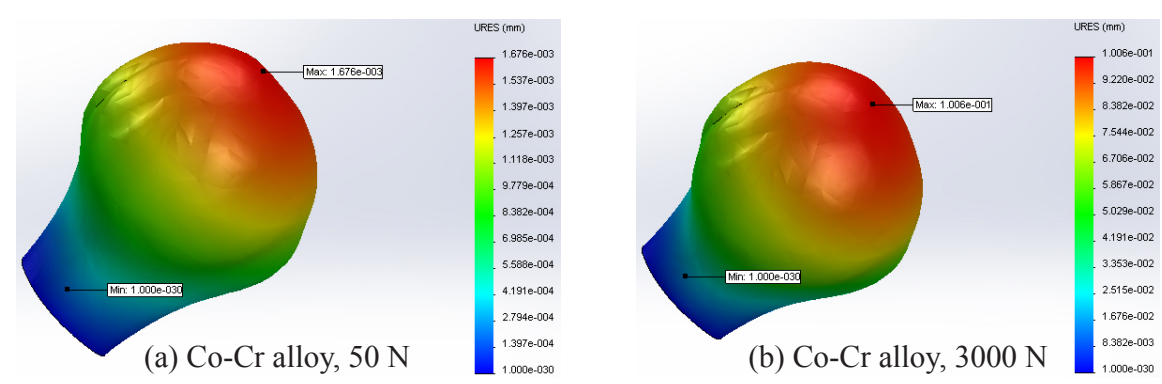

Fig. 8. 3D surface deformation of humeral head at different loads.

Comparative values of the maximum and the minimum surface deformation at different loads for the 3D anatomical and artificially-shaped $\mathrm{HH}$ made of different biomaterials are shown in Table 4.

Table 4

Maximum surface deformation ( $\mathrm{mm}$ ) for different $\mathrm{HH}$ biomaterials

\begin{tabular}{|c|c|c|c|c|}
\hline Load, N & Bone & Al-foam & Co-Cr & Ni-Ti \\
\hline 50 & 0.02038 & 0.05855 & 0.001676 & 0.004430 \\
\hline 3000 & 1.2230 & 3.5070 & 0.1006 & 0.2653 \\
\hline
\end{tabular}

Thus, Figs. 7, 8 as well as Tables 3,4 give accurate description of the new methodology for evaluating the surface shape of anatomical humeral heads. 


\section{DESIGN AND DEVELOPMENT OF 3D SURFACE MAPPING FOR ARTIFICIAL HUMERAL HEAD}

The methodology for stress and surface deformation analyses of artificially developed humeral heads (HHs) was worked out using SolidWorks software. The artificial components at a typical shoulder joint replacement include a humeral head made of matal-based biomaterial, and a glenoid made of polymeric biomaterial. This section focuses on the functioning of developed humeral head. The design of the artificial $\mathrm{HH}$ is done according to the precise measurements and the results of analysis (mentioned previously) using the AutoCAD tool (Fig. 9). The analysis was performed in order to obtain results about how the artificial design responds to different factors, such as load, type of material, and type of test. The dimensions of the global humeral head implant are assessed based upon the observed variability in humeral head sizes in the normal shoulder [17-18]. The stress and surface deformation analyses were done on the artificial $\mathrm{HH}$ using three different biomaterials: $\mathrm{Co}-\mathrm{Cr}$ alloy, Ni-Ti alloy, and Al-foam (their properties were described previously in Table 1).

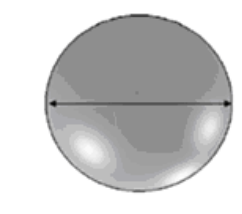

$48 \mathrm{~mm} \mathrm{HH}$ diameter

Elevation view

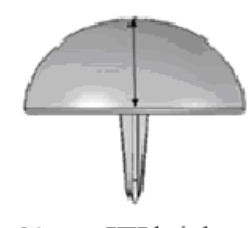

$21 \mathrm{~mm} \mathrm{HH}$ height

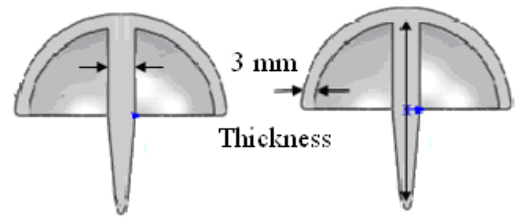

$6 \mathrm{~mm}$ Nail diameter

$40 \mathrm{~mm}$ Nail length

Side view

Fig.9. Dimensions of the humeral head (HH) design obtained using AutoCAD.

\subsection{D Stress Analysis of the Proposed Design for Artificial HH}

The 3D stress analysis of artificial humeral head from Co-Cr alloy exposed to different loads is illustrated in Fig. 10. The analysis is based on the finite-element (FE) simulation. The results are as follows. The use of $50 \mathrm{~N}$ compression load results in the minimum stress of $721.3 \mathrm{~N} / \mathrm{m}^{2}$ and the maximum of $120,509.8 \mathrm{~N} / \mathrm{m}^{2}$. The $3000 \mathrm{~N}$ compression load gives the minimum stress of $43.279 .9 \mathrm{~N} / \mathrm{m}^{2}$ and the maximum of $7,230,586.0 \mathrm{~N} / \mathrm{m} 2$.

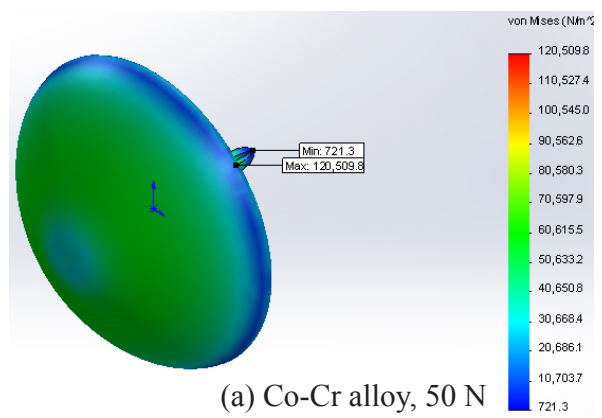

Fig. 10. 3D stress analysis of artificial humeral head.

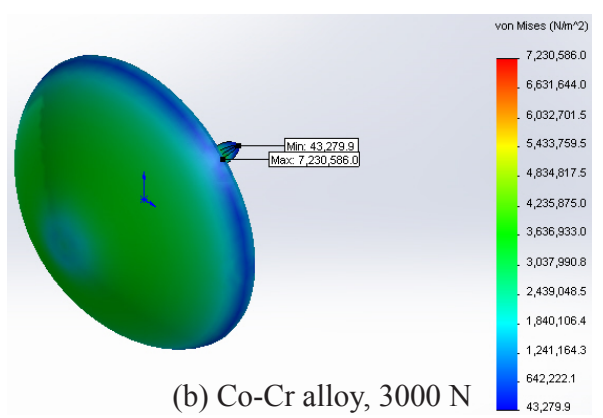

(b) Co-Cr alloy, $3000 \mathrm{~N}$ 
The stress analysis of the Al-foam humeral head at compressive loads is as follows.

The $50 \mathrm{~N}$ compression load generates the minimum stress point of $781.9 \mathrm{~N} / \mathrm{m}^{2}$ and the maximum of $116,997.0 \mathrm{~N} / \mathrm{m}^{2}$, while the $3000 \mathrm{~N}$ compression load produces the respective minimum/maximum stress values of $47,204.7 \mathrm{~N} / \mathrm{m}^{2}$ and $7,027,467.0$ $\mathrm{N} / \mathrm{m}^{2}$. In turn, the stress analysis of Ni-Ti alloy artificial humeral head under compressive loads is as follows. The $50 \mathrm{~N}$ compression load gives the minimum stress point of $817.9 \mathrm{~N} / \mathrm{m}^{2}$ and the maximum of $115,272.4 \mathrm{~N} / \mathrm{m}^{2}$, while the respective values using $3000 \mathrm{~N}$ compression load are $49,376.5 \mathrm{~N} / \mathrm{m}^{2}$ and $6,922,929.0 \mathrm{~N} / \mathrm{m}^{2}$. Comparison of the maximum and minimum stress analyses for $3 \mathrm{D}$ artificial $\mathrm{HH}$ using different biomaterials at $50 \mathrm{~N}$ and $3000 \mathrm{~N}$ loads is shown in Table 5.

Table 5

Minimum/maximum stress points $\left(\mathrm{N} / \mathrm{m}^{2}\right)$ of artificial humeral head

\begin{tabular}{|c|c|c|c|}
\hline Load, N & Al-foam & Co-Cr & Ni-Ti \\
\hline 50 & $782 / 116997$ & $721 / 120510$ & $818 / 115272$ \\
\hline 3000 & $47205 / 7027467$ & $43279 / 7230585$ & $49376 / 6922929$ \\
\hline
\end{tabular}

\subsection{D Surface Deformation Analysis of the Proposed Design for Artifi- cial HH}

The simulation results of the surface deformation analysis using FE SolidWorks are presented in Fig. 11 for Co-Cr alloy. The analysis for the $\mathrm{Co}-\mathrm{Cr}$ alloy based humeral head at compressive loads is as follows. The $50 \mathrm{~N}$ compression load generates the minimum surface displacement of $1.000 \mathrm{E}-030 \mathrm{~mm}$ and the maximum of 7.621E-006 mm as shown in Fig.11a. In turn, the $3000 \mathrm{~N}$ compression load produces the respective minimum/maximum displacement values of $1.000 \mathrm{E}$ $030 \mathrm{~mm} / 4.573 \mathrm{E}-004 \mathrm{~mm}$, see Fig. $11 \mathrm{~b}$. The surface deformation analysis of Al-foam humeral head at $50 \mathrm{~N}$ and $3000 \mathrm{~N}$ compression loads is as follows. The use of $50 \mathrm{~N}$ compression load results in the minimum displacement of $1.000 \mathrm{E}-030 \mathrm{~mm}$ and the maximum of $2.617 \mathrm{E}-004 \mathrm{~mm}$. The $3000 \mathrm{~N}$ compression load gives the minimum displacement of $1.000 \mathrm{E}-030 \mathrm{~mm}$ and the maximum of $1.570 \mathrm{E}-002 \mathrm{~mm}$.

The surface deformation analysis of Ni-Ti alloy artificial HH under compressive loads is as follows. The $50 \mathrm{~N}$ compression load gives the minimum displacement point of $1.000 \mathrm{E}-030 \mathrm{~mm}$ and the maximum of $1.969 \mathrm{E}-005 \mathrm{~mm}$, while the respective values using $3000 \mathrm{~N}$ compression load are $1.000 \mathrm{E}-030 \mathrm{~mm}$ and $1.660 \mathrm{E}-003 \mathrm{~mm}$.
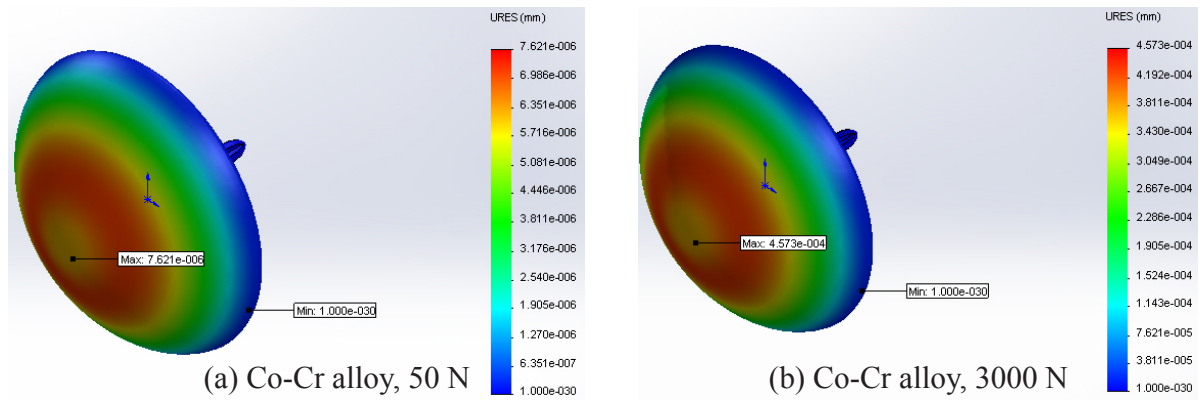

Fig.11. 3D surface analysis of artificial humeral head. 
Comparison of maximum and minimum deformation of surface for $3 \mathrm{D}$ artificially-shaped humeral head using different biomaterials and loads is shown in Table 6. Thus, the new methodology for evaluation of the surface shape of artificial HH has been accurately described.

Table 6

Maximum surface deformation ( $\mathrm{mm}$ ) of artificial humeral head

\begin{tabular}{|c|c|c|c|}
\hline Load, N & Al-foam & Co-Cr & Ni-Ti \\
\hline 50 & $2.617 \cdot 10^{-4}$ & $7.621 \cdot 10^{-6}$ & $1.969 \cdot 10^{-5}$ \\
\hline 3000 & 0.01570 & 0.000457 & 0.001166 \\
\hline
\end{tabular}

\section{RESULTS AND DISCUSSION}

The visualization capability for conversion of 2D image of anatomical humeral head bone into 3D image is illustrated in Fig. $2 b$. The dimensions and standard deviations of anatomical humerus bone found for different volunteers are shown in Fig.4. The measurement results for the humerus dimensions have been assessed and confirmed by comparison with the data of other researchers (see Fig.5). A methodology for the evaluation of humeral head in both anatomical bone shape and artificial shape has been accurately described above. It is of value to establish visual correspondence of 3D surface as shown in Figs.7-11 to recieve a good idea and intuitive sense of how to visualize the effect of compressive loads. However, the successful design of developed HHR requires verification of the impact of such loads in FE analysis. Series of FE computations that have been carried out to study the 3D distribution of the compression stresses and surface deformations for replacement of anatomical and artificial HHs are illustrated above. The predicted deviations of the surface mapping for the proposed artificially shaped humeral heads are presented in Figs. 12 and 13 for the optimum design conditions. The charts in Fig.12 present the maximum compression stress and the maximum deformation for different biomaterials at different applied loads. These charts show that the correlations between the applied force $(\mathrm{N})$ and either the compression stress $\left(\mathrm{N} / \mathrm{m}^{2}\right)$ or the surface deformation $(\mathrm{mm})$ are regulated linearly. With increase in the load applied under test, the compressive stress increases almost similarly for all the materials used. If there are large deviations in the surface responses, this is attributed to the degree of elasticity of material.

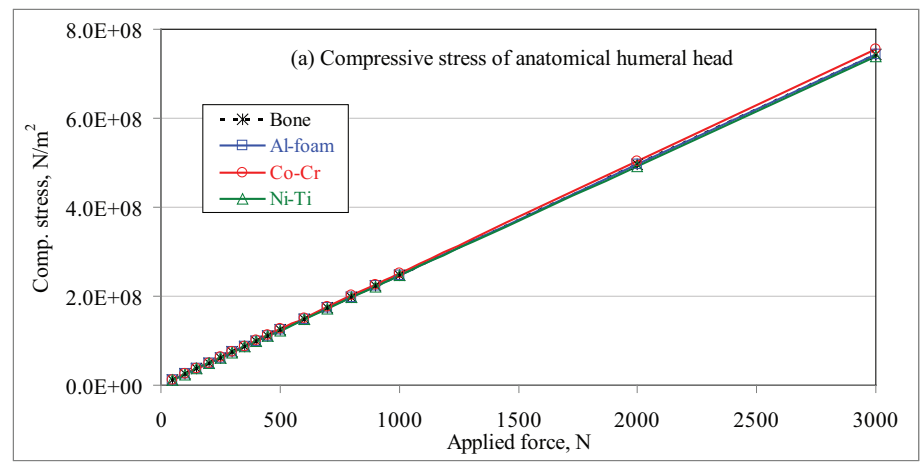




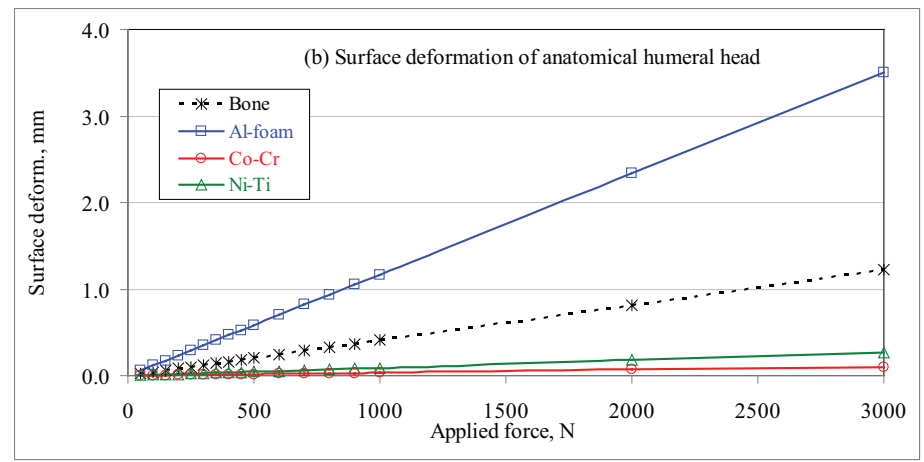

Fig. 12. Chart of: (a) compression stress; (b) surface deformation due to compression stress for the anatomical humeral head.

Figure 13 displays the charts for compression stress and surface deformation of selected biomaterials and their response to different applied loads for the 3D artificial humeral head at the same compression location. These charts show the linear correlations between the applied force $(\mathrm{N})$ and either compression $\left(\mathrm{N} / \mathrm{m}^{2}\right)$ or displacement (mm). Presented charts evidence that the $\mathrm{Co}-\mathrm{Cr}$ alloy has the best compression stress resistance, which might be due to the toughness of the alloy. The object made from Ni-Ti alloy has the worst compression stress resistance, probably due to its excessive elasticity. The best material for humeral head in the deformation test turned out to be the Co-Cr alloy owing to its ability to resist bending under compression, maybe due to the reduced yield. The aluminium foam material was the worst in the deformation test because of large spaces between the foam molecules i.e. owing to its low density. It appears that different biomaterials and their surface characteristics cause changes in the response of the material to different applied loads. Similar results were found by the authors of works $[19,20]$.
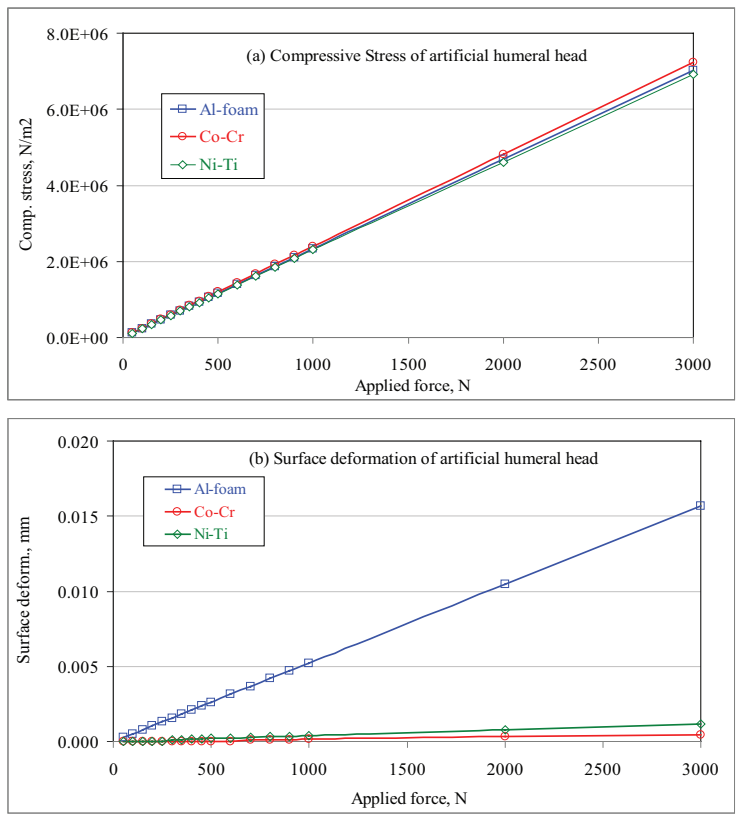

Fig. 13. Chart of: (a) compression stress; (b) surface deformation due to compression stress for the artificial humeral head. 
Obviously, it is difficult and somehow incorrect to provide a general overview of the physical activities of an individual based on the information collected on the typology of a single bone (humerus). Nevertheless, the combination of these results with other information collected by accurate anthropological analysis of the skeleton could be useful and would help in understanding the functional stress pattern generated by physical activities.

\section{CONCLUSIONS}

The proposed biomechanical design of artificial humeral head replacement (HHR) using different biomaterials has shown a good performance. The 3D FE analysis into the stress distribution and surface deformation mapping for different compressive loads applied to the humeral head are presented and discussed. Therefore, conclusions based on the results of studying the biomechanical design behavior are as follows.

1. CT scan as an accurate dimensional metrology technique helps to determine the dimensions of the bone of a human, which is important for developing the HHR design.

2. Conversion of the $2 \mathrm{D}$ CT image into a $3 \mathrm{D}$ image of the object could be performed efficiently based on the relevant measurements and analyses.

3. The mean length of humerus bone in males is greater than that of females within the accuracy of measurements. The obtained results for the dimensional assessment of the human humerus bone agree well with those found by other researchers.

4. Visualization realized due to the FE simulation allows identifying the response behaviors of humerus and humeral head - both natural and artificially shaped from biomaterials within different metrologies.

5. The humeral head based on Co-Cr alloy has the best resistance to compression stress and the minimum deformation of the surface as compared with other selected biomaterials (based on Ni-Ti alloy and Al-foam).

6. The aluminium foam shows the worst results of 3D surface deformation as compared with other biomaterials in the analysis ( $\mathrm{Ni}-\mathrm{Ti}$ and $\mathrm{Co}-\mathrm{Cr}$ alloy based) due to its high elasticity and low density.

7. It has been convincingly shown that the accurate dimensional metrology techniques play an important role in the study and interpretation of the biomechanical designs for engineering objects.

8. Analysis of the results provides a possibility to further optimize the HHR design so that it is suitable for the total shoulder joint replacement.

\section{ACKNOWLEDGEMENTS}

The author-unforgettable and prays for mercy to Prof. Dr. Abdalla Mohamed for his valuable advices before start this work. Dr. Abdalla died in October 2013. He was Emeritus Professor in the Systems and Biomedical Engineering Dept., Faculty of Eng., Cairo University, Egypt. I would like to thank all those who run the CT scan and program under my supervision. 


\section{REFERENCES}

1. Salah H. R. Ali (2012). Advanced Nanomeasuring Techniques for Surface Characterization. ISRN Optics, pp.1-23, ID 859353.

2. Salah H.R. Ali, Marwah M.A. Almaatoq \& Abdalla S.A. Mohamed (2013). Recent Progress in Nanometrology Techniques for Object Characterization. Intern. Journal of Eng. Research and Applications, 3(4), 1343-1366.

3. Salah H.R. Ali \& Sarwat Z.A. Zahwi (March 2014). CT Measurement and Analysis of Geometrical Shape for Human Shoulder Glenoid. Intern. Review of Mechanical Engineering (IREME), 8(2), 370-378.

4. Armfield, D.R., Stickle, R.L., Robertson, D.D., Towers, J.D., \& Debski, R.E. (2003). Biomechanical Basis of Common Shoulder Problems. Semin Musculoskeletal Radiology, 7(1), 5-18.

5. Bobrowitsch, E., Imhauser, C., Graichen, H., \& Durselen, L. (2007). Evaluation of a 3D Object Registration Method for Analysis of Humeral Kinematics. Journal Biomech., 40(3), 511-518.

6. Salah, H.R. Ali , Bedewy M.K., Etman M.A., Khalil H.A. \& Azzam B.S., (2010). Morphology and Properties of Polymer Matrix Nanocomposites. Intern. Journal of Metrology and Quality Eng., 1(1), 33-39.

7. MakeItFrom, Materials Properties Database, cobalt chromium alloy physical properties, Copyright 2009-13. On the Website at: http://www.makeitfrom.com/materialdata/?for $=$ Co-28Cr-6Mo-Cobalt-Chromium-Alloy

8. Buehler W. J., Gilfrich J. V. \&. Wiley R. C, (1963). Effect of Low Temperature Phase Changes on the Mechanical Properties of Alloys near Composition TiNi. Journal of Applied Phys., 34(5), 1475.

9. MakeItFrom, Materials Properties Database, Aluminum Foam Physical Properties. On the Website at: http://www.makeitfrom.com/material-data/?for=Aluminum-Foam

10. M-L Yeh, M.H. Heggeness, H-H. Chen, J. Jassawalla \& Z-P. Luo (2006). Compressive Loading at the end Plate Directly Regulates Flow and Deformation of the Basivertebral vein: An Analytical Study. Journal of Orthopedic Surgery and Research, 1(18), 1-6.

11. 3-matic Software, Biomedical Software for Engineering on Anatomy, Puts the "Engineering" in Engineering on Anatomy. On the Website at: http://biomedical.materialise. com/3-matic

12. 3D CAD Design SolidWorks Software, Dassault Systèmes SolidWorks Corp, France. On the Website at: http://www.solidworks.com

13. W. Jonathan, The DICOM Standard, Kortrijk, Belgium, (2007). On the Website at: http:// www.barco.com/barcoview/downloads/TheDICOMstandard_v2.pdf

14. Salah, H. R. Ali, Hassan, H. Mohamed, \& Mohamed, K. Bedewy (2009). Identifying cylinder liner wear using precise coordinate measurements. Intern. Journal of Precision Engineering and Manufacturing, 10(5), 19-25.

15. Papaloucas, M., Papaloucas, C., Tripolitsioti, A., \& Stergioulas, A. (2008). The Asymmetry in Length between Right and Left Humerus in Humans. Pakistan Journal of Biological Sciences, 11, 2509-2512.

16. Somesh, M. S., Prabhu, L. V., Shilpa, K., Pai, M. M., Krishnamurthy, A. \& Murlimanju, B. V. (2011). Morphometric study of the humerus segments in Indian population. Intern. J. Morphol., 29(4), 1174-1180. 
17. Peidro L., Plaza R., \& Sastre S., (2008). Perioperative Fracture-Dislocation of the Humeral Head During A Resurfacing Hemiarthroplasty. Intern. J. Shoulder Surg., 2 (2), 41-42.

18. Widnall, J.C., Dheerendra, S.K., Macfarlane, R.J. \& Waseem, M. (2013). The use of Shoulder Hemiarthroplasty and Humeral Head Resurfacing. A Review of Current Concepts, Open Orthop., 7, 334-337.

19. Chen, QZ, Zhu, C.H., \& Thuas, G.T. (2012). Progress and challenges in biomaterials for bone tissue engineering. Progress in Biomaterials, 1-2 (1:2), 1-22.

20. Ping Hai-Tao, Wu Zhi-Lin \& Mo Gen-Lin (2011). Improvement measures and application of parametric design of machine parts based on SolidWorks API. Coal Mine Machinery, 32(1), 235-238.

\section{MODERNIZĒTS DIZAINS PLECA KAULA GALVIN̦AS NOMAIN̦AI, IZMANTOJOT TRİSDIMENSIJU VIRSMAS ATTĒLOŠANU}

Salah H. R. Ali

K ops a vi $1 \mathrm{ku} \mathrm{m} \mathrm{s}$

Izmēru un ǵeometrisko datu novērtējums, kas attiecas uz pleca kaula galviņas nomaiņas (PKGN) objektiem, nepieciešams, lai risinātu virkni reversīvās inženierijas (RI) problēmu. Šajā darbā cilvēka pleca kaula galviṇas divdimensiju novērtējums tika veikts ar datortomogrāfijas palīdzību (RI) ietvaros, un pēc tam objekta divdimensiju attēlojums tika pārveidots trīsdimensiju. Pārveidojums bija sekmīgs, parādot pleca kaula galviņas izmēru un ǵeometrijas atšksirības starp 2D un 3D novērtējumiem. Autori izanalizēja un eksperimentāli apstiprināja statistisko informāciju pēc dotā veida anatomiskiem objektiem. Saspiešanas sasprindzinājumi, kuri ietekmē trīsdimensiju virsmas attēlojuma ǵeometriju, tika analizēti ar gala-elementu simulācijas metodi, lietojot programmu SolidWorks. Biomehaniskajam PKGN dizainam tika atlasīti piemēroti materiāli. Apspriesta dažādu biomateriālu ar metālisko pamatu reakcija uz mainīgām slodzēm. Tiek piedāvāta pleca kaula galviņas - kā anatomiskas, tā mākslīgas - trīs dimensijas mērǐšanas metodologijas. Dota datortomogrāfisko precīzo mērījumu rezultātu detalizēta interpretācija.

16.05.2014. 